\title{
The Frequency of Diabetes among People with Dyslipidemia in Kyrgyzstan (The Steps Survey)
}

\author{
Sultanalieva $\mathbf{R}$ \\ Department of Therapeutic Endocrinology, Kyrgyz-Russian Slavonic University, Kyrgyzstan
}

Submission: August 19, 2018; Published: November 20, 2018

*Corresponding author: Sultanalieva R, Department of Therapeutic Endocrinology, Kyrgyz-Russian Slavonic University, Bishkek, Kyrgyzstan

Abstract

The present study examines the influence of dyslipidemia on the risk of type 2 diabetes mellitus in Kyrgyzstan.

Keywords: Type 2 diabetes mellitus; Dyslipidemia; Risk factors; Prevalence.

Abbreviations: T2DM: Type 2 Diabetes Mellitus; CVD: Cardiovascular Diseases, IR: Insulin Resistance

\section{Introduction}

Insulin resistance and T2DM are characterized by the development of dyslipidemia - the main factor of CVD. Before the development of diabetes, IR can manifest itself as dyslipidemia [1]. The recent studies have demonstrated that changes in lipids can not only be the consequence of impaired glucose metabolism but can also be its cause. The increased amount of free fatty acids damages insulin receptors and disrupts the normal functioning of $\beta$-cells [2]. Around $50 \%$ to $84 \%$ of people with diabetes have hypercholesterolemia [3]. One of the few studies conducted by Polupanov et al. in Kyrgyzstan shows that the overall incidence of hyperlipidemia in the sample was $88.4 \%$ without significant gender differences $(86.8 \%$ in men and $89.6 \%$ in women [4]. Even though several studies examined the prevalence of diabetes and hypercholesterolemia, none of them analyzed the effect of high cholesterol on the risk of diabetes. Therefore, for the first time we decided to study this issue covering all regions of the country. The goals of our study were to determine the true prevalence of hypercholesterolemia and carbohydrate metabolism disorders in Kyrgyzstan, to assess the effect of high cholesterol on the development of diabetes, and to summarize the data obtained from other studies.

\section{Materials and Methods}

The STEPS survey was conducted in Kyrgyzstan in the period from October 2013 to November 2013. The selection of the population for the study was carried out by random sampling from all regions of the Republic in relation to the general population. A total of 2585 people were examined including 926 (35.8\%) men, 1659 (64.1\%) women, aged 25 to 65 years, the average age was $43.8 \pm 0.22$ years (the average age of men - $44.0 \pm 0.36$; women $43.8 \pm 0.27, p>0.05$ ). All people signed an informed consent. The survey was based on the WHO STEPS questionnaire, which ex amined the following indicators: education, work data, smoking, alcohol consumption, physical activity levels, and eating habits [5]. The next step consisted of a physical assessment that included the measurement of blood pressure (BP), heart rate (HR), height, weight, waist (WC) and hips (HC). Analysis of glucose was performed using CardioChek meter (Germany) in capillary blood. Parameters, such as fasting plasma glucose (FPG) and total cholesterol, were investigated. The measurement of glucose was carried out according to WHO criteria [6]. Total cholesterol was estimated according to the American Heart Association criteria -2013. Espino version 2007 and SPSS 11.0 versions were used for statistical processing. The processing determined mean values $(M)$, standard deviation $(\delta)$, representativeness error $(m)$, intensive and extensive values, and $95 \%$ confidence interval (CI). To compare the dependence of numerical series the study used Spearman's correlation coefficient $(\mathrm{rx}, \mathrm{y})$ and determination coefficient $(\mathrm{R}, \%)$. The main indicator of the influence of one factor to another was the method of relative risk assessment (relative risk, HR) and factor analysis. The differences with $\mathrm{p}<0.05$ were considered significant.

\section{Results and Discussion}

The STEPS survey measured only fasting glycemia in plasma from capillary blood to assess carbohydrate metabolism disorders. The mean level of FPG in the examined population was $4.9 \pm 0.03 \mathrm{mmol} / \mathrm{l}(4.8 \pm 0.05$ in men, $4.9 \pm 0.04 \mathrm{mmol} / \mathrm{l}$ in women, $\mathrm{p}>0.05$ ). Because analysis was performed once and only on an empty stomach with the use of a glucometer, the diagnosis of "diabetes" was unlawful, so the following criteria for assessing glycemia were used: hyperglycemia is more or equal to $7 \mathrm{mmol} / \mathrm{l}$ and hyperglycemia is more or equal to $6.1 \mathrm{mmol} / \mathrm{l}$, but less than $7 \mathrm{mmol} / \mathrm{l}$. Hyperglycemia $\geq 7 \mathrm{mmol} / \mathrm{l}$ was registered in $5.4 \%$ of 
cases, hyperglycemia $\geq 6.1 \mathrm{mmol} / \mathrm{l}$, but $<7 \mathrm{mmol} / \mathrm{l}$ - in $5.8 \%$. The analysis determined the effect of increased total cholesterol on the risk of hyperglycemia. The level of mean total cholesterol in the population of the examined patients was $4.4 \pm 0.01 \mathrm{mmol} / \mathrm{l}$. Both men and women had the same- $4.4 \pm 0.03$ and $4.4 \pm 0.02$ $\mathrm{mmol} / \mathrm{l}$, respectively ( $\mathrm{p}>0.05$ ). At the same time, $25.1 \pm 0.85 \%$, i.e. a quarter of all examined patients had the level of total cholesterol more than $5 \mathrm{mmol} / \mathrm{l}$, or hypercholesterolemia $(23.3 \pm 1.3 \%$ of men, $26,1 \pm 1.0 \%$ of women>0.05). The frequency of hyperglycemia $\geq 7 \mathrm{mmol} / \mathrm{l}$ and hyperglycemia from 6.1 to $7.0 \mathrm{mmol} / \mathrm{l}$ with high confidence were higher among people with high total cholesterol (Table 1).

Table 1: Frequency of hyperglycemia depending on the presence of hypercholesterolemia

\begin{tabular}{|c|c|c|c|c|c|c|}
\hline \multirow{2}{*}{ No } & \multirow{2}{*}{ Blood Glucose, mmol/l } & Normal Total Cholesterol & Hyper Cholesterolemia & \multirow{2}{*}{$\mathbf{R R}$} & \multirow{2}{*}{$95 \% \mathrm{CI}$} & \multirow{2}{*}{$\mathbf{p}$} \\
\hline & & $\mathrm{P} \pm \mathrm{m}, \%$ & $\mathrm{P} \pm \mathrm{m}, \%$ & & & \\
\hline \multicolumn{7}{|c|}{ Men $(n=926)$} \\
\hline 1 & Hyperglycemia $\geq 7,0$ & $3,8 \pm 0,6$ & $9,2 \pm 1,75$ & 1,3 & $1,0-1,7$ & $<0,001$ \\
\hline 2 & Hyperglycemia $\geq 6,1,<7,0$ & $4,2 \pm 0,65$ & $8,3 \pm 1,65$ & 1,2 & $0,9-1,2$ & $<0,01$ \\
\hline \multicolumn{7}{|c|}{ Women $(n=1659)$} \\
\hline 1 & Hyperglycemia $\geq 7,0$ & $5,0 \pm 0,55$ & $7,1 \pm 1,0$ & 1,1 & $0,9-1,2$ & $<0,01$ \\
\hline 2 & Hyperglycemia $\geq 6,1,<7,0$ & $5,1 \pm 0,55$ & $9,2 \pm 1,2$ & 1,2 & $1,0-1,4$ & $<0,001$ \\
\hline \multicolumn{7}{|c|}{ Total $(n=2585)$} \\
\hline 1 & Hyperglycemia $\geq 7,0$ & $4,6 \pm 0,47$ & $7,8 \pm 1,0$ & 1,1 & $1,0-1,3$ & $<0,01$ \\
\hline 2 & Hyperglycemia $\geq 6,1,<7,0$ & $4,8 \pm 0,48$ & $8,9 \pm 1,1$ & 1,2 & $1,0-1,3$ & $<0,001$ \\
\hline
\end{tabular}

Note: $\mathrm{R} \pm \mathrm{m}$ - The frequency and margin of error, RR- Relative risk, $\mathrm{Cl}-95 \%$ confidence interval, P-confidence of differences between groups.

The correlation between TC and FPG was+0.18 ( $p<0.001)$, weakly positive. The degree of influence (coefficient of determination) was equal to $3.2 \%$. The increase in TC to a small extent influenced FPG. Thus, the increase in cholesterol was a significant factor affecting the level of glycemia, and therefore, the presence of hyperglycemia in combination with hypercholesterolemia currently requires timely treatment and multi-factor approach in order to prevent these conditions.

\section{Conclusion}

Undiagnosed disorders of carbohydrate metabolism in combination with increased cholesterol levels are widespread among the population of Kyrgyzstan. The increased level of cholesterol has direct impact on the frequency of carbohydrate metabolism abnormalities. High cholesterol increases the risk of hyperglycemia 1.1-1.3 times.

\section{References}

1. Tangvarasittichai S (2015) Oxidative stress, insulin resistance, dyslipidemia and type 2 diabetes mellitus. World J Diabetes 6(3): : 456-460.
2. Parhofer KG (2015) Interaction between Glucose and Lipid Metabolism: More than Diabetic Dyslipidemia. Diabetes Metab J 39(5): 353-362.

3. De la Sierra A, Pinto X, Guijarro C, Miranda JL, Callejo D, et al. (2015) Prevalence, Treatment, and Control of Hypercholesterolemia in High Cardiovascular Risk Patients: Evidences from a Systematic Literature Review in Spain. Adv Ther 32(10): 944-961.

4. Полупанов АГ, АН Халматов, МТ Махмудов, ЖА Мамасаидов, НБ Ческидова, et al. (2014) Распространенность дислипидемий среди жителей кыргызской республики трудоспособного возраста (по данным международного исследования “ИНТЕРЭПИД”). Вестник КРСУ. Том 14(5):45-48.

5. Little M, Sally Humphries, Kirit Patel, Warren Dodd, Cate Dewey (2016) Factors associated with glucose tolerance, pre-diabetes, and type 2 diabetes in a rural community of south India: a cross-sectional study. Diabetol Metab Syndr 8: 21.

6. Shera AS, Basit A, Fawwad A, Hakeem R, Ahmedani MY (2010) Pakistan National Diabetes Survey: prevalence of glucose intolerance and associated factors in the Punjab Province of Pakistan. Prim Care Diabetes 4(2): 79-83.

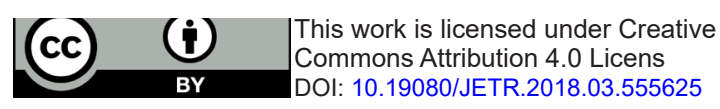

Your next submission with Juniper Publishers
will reach you the below assets
- Quality Editorial service
- Swift Peer Review
- Reprints availability
- E-prints Service
- Manuscript Podcast for convenient understanding
- Global attainment for your research
- Manuscript accessibility in different formats
( Pdf, E-pub, Full Text, Audio)
- Unceasing customer service
Track the below URL for one-step submission
https://juniperpublishers.com/online-submission.php

